Vol 14, Issue 5, 2021

\title{
INVESTIGATION OF ANALGESIC, ANTIOXIDANT, AND CYTOTOXIC PROPERTIES OF THE ETHANOLIC EXTRACT OF STREBLUS ASPER (ROOTS)
}

\author{
ANANTA KUMAR DAS ${ }^{1}$, ROZINA PARUL ${ }^{1 *}$, MD. MONIRUL ISLAM ${ }^{1}$, APU CHANDRA GHOSH ${ }^{1}$, MD. JAHIR ALAM ${ }^{2}$ \\ ${ }^{1}$ Department of Pharmacy, Gono Bishwabidyalay, Mirzanagar, Savar, Dhaka. ${ }^{2}$ Department of Pharmacy, Jahangirnagar University, Savar, \\ Dhaka. Email: rozinaparul.ju@gmail.com
}

Received: 31 August 2020, Revised and Accepted: 23 March 2021

\section{ABSTRACT}

Objective: This study evaluated the analgesic, antioxidant, and cytotoxic effects of ethanolic extract of Streblus asper roots.

Methods: Analgesic activities were carried out using paw licking and writhing tests. The extract was used at doses of 250 and 500 mg/kg per orally in Swiss albino mice of body weight 25-30 g. Antioxidant properties were investigated using 1, 1-diphenyl-1-picrylhydrazyl free-radical scavenging assay, total phenol content, total flavonoid content as well as reducing power capacity. The cytotoxic activity was determined by the Brine Shrimp lethality bioassay.

Results: The ethanolic extract of $S$. asper roots showed a significant effect in the formalin test $(\mathrm{p}<0.01)$. They also exhibit the highest analgesia $(\mathrm{p}<0.01)$ in the acetic acid-induced writhing model as well. The extract possessed antioxidant effects in all the models. It possessed a good cytotoxic activity.

Conclusion: The results suggested that $S$. asper root extract has a suitable analgesic, antioxidant effect as well as significant cytotoxic potential.

Keywords: Streblus asper, Analgesic, Antioxidant, Cytotoxicity, 1, 1-diphenyl-1-picrylhydrazyl free-radical scavenging assay.

(C) 2021 The Authors. Published by Innovare Academic Sciences Pvt Ltd. This is an open access article under the CC BY license (http://creativecommons.org/ licenses/by/4.0/) DOI: http://dx.doi.org/10.22159/ajpcr.2021v14i5.39520. Journal homepage: https://innovareacademics.in/journals/index.php/ajpcr

\section{INTRODUCTION}

Pain is a sensorial modality, primarily protective, but often causes discomfort. It is the most important symptom that brings the patient to the physician. Conventional medicine, including treatments with steroids and nonsteroidal anti-inflammatory drugs, has shown only limited success against all forms of inflammatory conditions and pains associated with unpleasant side effects such as gastrointestinal disturbances [1].

Free radicals are chemical species possessing an unpaired electron and are implicated in the progression of a variety of disorders in humans including central nervous system injury, arthritis, atherosclerosis, ischemic heart diseases, gastritis, and cancer and reperfusion injury of many tissues [2-5]. Oxidative stress results when the generation of reactive oxygen species (ROS) supersedes incompetence with cellular antioxidant defenses [6]. Mainly, the existence of phenolic cancer prohibition factors is acknowledged to have the covering mechanisms thus these phenolic compounds have antioxidative properties that useful as cancer chemo-preventive agents and at most inhibit carcinogenesis during the initiation phase, since they act as radical scavengers, for example, ROS [7]. The antioxidant present in the markets is mostly synthetic. Such synthetic antioxidants are known to have potential side effects and toxicity. Hence, their use is being restricted nowadays and there is increasing interest in finding out safer and bioactive natural antioxidants present in plant species [8].

Toxicology is just pharmacology at a higher dose. Thus, if we find toxic compounds, a lower, non-toxic, dose might elicit a useful, pharmacological, and perturbation on a physiologic system [9].

Since a very ancient time, herbal medications have been used for the relief of symptoms of disease [10]. The secondary metabolites found in plants and exhibit health beneficial activities such as antioxidant, anti-inflammatory, antihepatotoxic, antitumor, and antimicrobial [11].
Despite the great advances observed in modern medicine in recent decades, much interest, in medicinal plants, however, emanates from their long use in folk medicines in developing countries [9]. The biodiversity of the flora of Bangladesh is very broad, and several native Bangladeshi medicinal plant species have a long history of use with great phyto therapeutic potential [12].

Streblus asper (known as Sheora in Bengali), of the Moraceae family, is indigenous to Bangladesh, India, Sri Lanka, Malaysia, the Philippines, Thailand, and Vietnam [13-16]. It is an evergreen, dioecious, or rarely monoecious tree, to $10 \mathrm{~m}$ high, barks $10-20 \mathrm{~mm}$ thick, fibrous; exudation milky white latex; leaves simple, alternate, spiral; and stipules 2-5 mm long [17]. S. asper is a well-known ethnomedicinal plant that is used as an anti-inflammatory, anticancer, an antidote to snakebite, gingivitis, to treat wounds, skin diseases, filariasis, leprosy, toothache, fever, diarrhea, and dysentery and is especially effective in the oral cavity, also used in menorrhagia, epilepsy, stomachache, and urinary complaints in folk medicines [15,18-24]. The literature review showed that the methanol extract of $S$. asper (roots) has better activity than other extracts. However, no study appears about analgesic, antioxidant, and cytotoxicity of the ethanolic extract as analgesic, antioxidant, and cytotoxic effect of $S$. asper (roots). Therefore, the present study aimed to evaluate the analgesic, antioxidant, and cytotoxic effect of $S$. asper (roots).

\section{METHODS}

Plant collection and identification

The roots of $S$. asper were collected from Dhamrai under the Dhaka district. The plant species were taxonomically identified and authenticated by the Bangladesh National Herbarium, Mirpur, Dhaka.

\section{Preparation of the extract}

The collected materials were shed dry at below $40^{\circ} \mathrm{C}$ and pulverized in an electric grinder. The powdered crude drug of S. asper roots (500 g) 
was subjected to a Soxhlet extraction process with $96 \%$ ethanol. The extract was filtered and evaporated to dryness in a rotary evaporator under reduced pressure to a solid mass and denoted as SA (Streblus asper ethanolic extract)

\section{Experimental animals}

Male Swiss Albino Mice (25-30 g) were used and collected from the animal research lab of the Department of Pharmacy, Jahangirnagar University, Savar, Dhaka-1342, Bangladesh. The animals were randomly distributed into groups, housed in cages and maintained under standard environmental conditions and had free access to feed and water ad libitum. All protocols for animal experiments were subject to approval by the institutional animal ethics committee.

\section{Acute toxicity studies}

Swiss albino mice of either sex (25-30 g weight) were used for acute oral toxicity studies. No adverse effects or mortality were detected in the mice up to $4.0 \mathrm{~g} / \mathrm{kg}$, p.o., during the $24 \mathrm{~h}$ observation period. Based on the results obtained from this study, the dose for analgesic and activity was fixed to be 250 and $500 \mathrm{mg} / \mathrm{kg} \mathrm{B.W}$. for dose-dependent study.

\section{Analgesic activity}

Acetic acid-induced writhing test

The method, according to Koster et al., 1959 was employed for this test. Forty-five minutes after administration time each mouse was injected with $0.7 \%$ acetic acid at a dose of $10 \mathrm{ml} / \mathrm{kg}$ intraperitoneal body weight. The number of writhing responses was recorded for each animal during a subsequent 5 min period after $15 \mathrm{~min}$ of the intraperitoneal administration of acetic acid and the mean abdominal writhes for each group were obtained [25].

\section{Formalin-induced paw licking test}

The method used by Hunskaar and Hole 1987 was used for the study. After $1 \mathrm{~h}$ of drug administration, $2.7 \%$ formalin was injected into the dorsal surface of the left hind paw. Time spent licking the injecting paw was recorded. The animals were found for the $5 \mathrm{~min}$ post formalin (acute phase) and for $5 \mathrm{~min}$ starting at $20^{\text {th }}$ min post formalin (delayed phase) [26].

\section{Antioxidant activity evaluation}

\section{1, 1-diphenyl-1-picrylhydrazyl (DPPH) free-radical scavenging assay}

The free-radical scavenging activity of the crude ethanolic extract was identified using the DPPH free radical method Silva IK, Soysa P, 2011. Various concentrations of the samples were an addition to $3 \mathrm{ml}$ of methanol DPPH solution that was prepared daily. The mixture was shaken and left to stand at room temperature in the dark. After $30 \mathrm{~min}$, the absorbance was measured at $517 \mathrm{~nm}$ against a blank containing all of the reagents except for the test samples. Ascorbic acid was served as a positive control. The $\mathrm{IC}_{50}$ (the concentration needed for $50 \%$ inhibition of DPPH) was calculated using the plot of percentage inhibition versus the extract concentration in $\mu \mathrm{g} / \mathrm{ml}$ [27]. The percentage of DPPH inhibition was calculated using the following equation:

$\%$ inhibition $\left.=\mathrm{A}_{0}-\mathrm{A} / \mathrm{A}_{0}\right) \times 100$

Where,

$\mathrm{A}_{0}$ is the absorbance of DPPH (control), and A is the absorbance of the sample with DPPH.

\section{Determination of total flavonoid content}

The total flavonoid content was calculated using the method described by Ordonez et al., 2006 with slight modification. To $1.0 \mathrm{ml}$ of samples/ standard, $3.0 \mathrm{ml}$ of methanol, $200 \mu \mathrm{l}$ of $10 \%$ aluminum chloride, $200 \mu \mathrm{l}$ of $1 \mathrm{M}$ potassium acetate solution, and $5.6 \mathrm{ml}$ of distilled water were added. After $30 \mathrm{~min}$ of incubation at room temperature, the absorbance was measured at $415 \mathrm{~nm}$. The total flavonoid content was reflected in terms of quercetin equivalent, $\mathrm{QE}, \mathrm{mg} / \mathrm{g}$ of the dry extract [28]

\section{Determination of total phenol content}

The total phenol content of SA extract/standard was determined as described using Folin-Ciocalteu reagent and Gallic acid as a standard [29,30]. $1 \mathrm{ml}$ of SA in methanol $(200 \mu \mathrm{g} / \mathrm{ml})$ was mixed with 5 $\mathrm{ml}$ of Folin-Ciocaleu's (1:10 v/v) reagent. After $3 \mathrm{~min}, 4 \mathrm{ml}$ of a saturated solution of $\mathrm{Na}_{2} \mathrm{CO}_{3}(7.5 \%)$ was inserted. After $1 \mathrm{~h}$ (but 30 min for the standard), the absorbance was measured spectrophotometrically at $765 \mathrm{~nm}$, and the results were expressed as mg Gallic acid equivalent (GAE) per g of extract (mg GAE/g). The methanol solution was used as a blank.

\section{Reducing power capacity assessment}

The ferrous reduction antioxidant capacity of samples/standard (Ascorbic acid) was evaluated by the method described by Islam et al., with slight modification. $2 \mathrm{ml}$ samples/standard solutions at different concentrations and $2.5 \mathrm{ml}$ of $1 \%$ potassium ferricyanide solution were added into the test tubes. The reaction mixture was incubated for $10 \mathrm{~min}$ at $50^{\circ} \mathrm{C}$ to complete the reaction. Then, a $2.5 \mathrm{ml}$ of $10 \%$ TCA (Trichloro Acetic Acid) solution was in addition to the test tubes. The total mixture was centrifuged at $3000 \mathrm{rpm}$ for $10 \mathrm{~min}$. After this, $2.5 \mathrm{ml}$ supernatant was withdrawn from the test tubes and was mixed with $2.5 \mathrm{ml}$ of distilled water and $0.5 \mathrm{ml}$ of $0.1 \% \mathrm{FeCl}_{3}$ solution. The absorbance of the solution was measured at $700 \mathrm{~nm}$ using a spectrophotometer against a typical blank [31]

\section{Cytotoxicity test (brine shrimp lethality bioassay [BSLT])}

BSLT is a rapid and comprehensive bioassay for the bioactive compounds of natural and synthetic origin [32]. Artemia salina leach (brine shrimp eggs) collected from pet shops was used as the test organism. Seawater was taken in a $1000 \mathrm{ml}$ beaker and shrimp eggs were added to one side of the beaker and then this side was covered. Two days were allowed to hatch the shrimp and to be matured as nauplii. Ten nauplii were taken carefully by micropipette. Thirty-two milligrams of the test sample were taken and dissolved in $200 \mu \mathrm{l}$ of pure dimethyl sulfoxide and the final volume was made to $20 \mathrm{ml}$ with seawater. Thus, the concentration of the stock solution was $1600 \mu \mathrm{g} / \mathrm{ml}$. Then, the solution was serial diluted to $800,400,200,100,50,25,12.5$, and $6.25 \mu \mathrm{g} / \mathrm{ml}$ with seawater. Then, $2.5 \mathrm{ml}$ of plant extract solution was an addition to $2.5 \mathrm{ml}$ of seawater containing 10 nauplii. After $24 \mathrm{~h}$, the test tubes were inspected using a magnifying glass against a black background and the number of surviving nauplii in each tube was counted. From this data, the percentage of the lethality of the brine shrimp nauplii was calculated for each concentration. The effectiveness of the concentration-mortality relationship of plant products is usually expressed as a median lethal concentration $\left(\mathrm{LC}_{50}\right)$ value.

\section{Statistical analysis}

Correlation/Regression analysis by Microsoft Office Excel was used as a statistical tool for analgesia inhibition assay data, inhibitory concentration, and cytotoxicity assay data. Statistical analysis for animal experiments was carried out by independent-sample t-test using SPSS. The data were presented as mean \pm SEM/SD. The results obtained were compared with the vehicle control group where $\mathrm{p}<0.05$, $<0.01$, and $<0.001$ were considered to be statistically significant, highly significant, and very highly significant, respectively.

\section{RESULTS}

\section{Analgesic activity}

The result of the present study of $S$. asper ethanolic extract is exhibited in Tables 1 and 2 .

\section{Antioxidant effect}

The $\mathrm{IC}_{50}$ values of DPPH radical scavenging activity are shown in Table 3 and Fig. 1.

The total content of phenolic compounds of ethanolic extract was determined from the regression equation of the calibration curve $\left(y=0.014 x+0.219, R^{2}=0.996\right)$ and expressed in GAE shown in Table 4 and Fig. 2. 


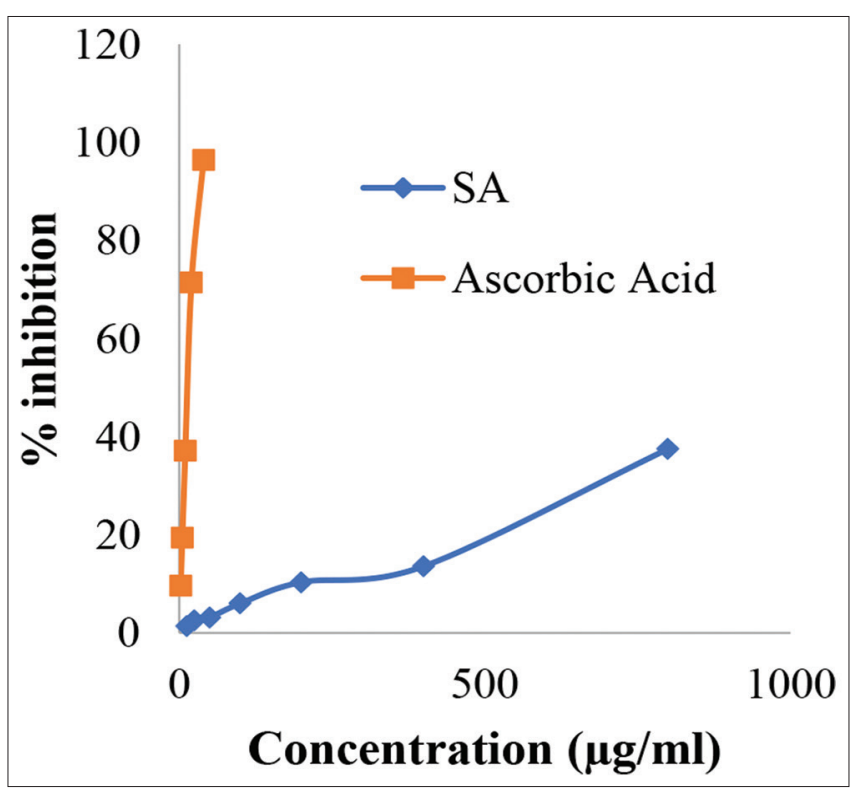

Fig. 1: 1, 1-diphenyl-1-picrylhydrazyl radical scavenging activity of ascorbic acid and SA ethanolic extract



Fig. 2: Calibration curve of gallic acid

Table 1: The effect of control, STD, SA $250 \mathrm{mg}$, and SA $500 \mathrm{mg}$ in the acetic acid-induced writhing test

\begin{tabular}{lllll}
\hline Group & $\begin{array}{l}\text { No. of } \\
\text { writhing } \\
\text { (Mean } \pm \text { SEM) }\end{array}$ & $\begin{array}{l}\text { T/p } \\
\text { value }\end{array}$ & $\begin{array}{l}\mathbf{9 5 \%} \\
\text { confidence } \\
\text { interval. }\end{array}$ & $\begin{array}{l}\text { \% } \\
\text { inhibition } \\
\text { of pain }\end{array}$ \\
\hline Control & $11.17 \pm 0.65$ & & & 00 \\
Std & $1.17 \pm 0.48^{* * *}$ & $\begin{array}{l}12.35 / \\
\text { (Diclofenac-Na) }\end{array}$ & 8.20 to 11.81 & 89.53 \\
SA 250 mg & $10.50 \pm 0.69^{*}$ & $\begin{array}{l}0.000 \\
0.41 /\end{array}$ & -3.16 to 4.50 & 6.00 \\
& & 0.022 & & \\
SA 500 mg & $7.83 \pm 0.83^{*}$ & $\begin{array}{l}3.15 / \\
0.010\end{array}$ & 0.97 to 5.69 & 29.90 \\
& & 0.010 & \\
\hline
\end{tabular}

N.B: ${ }^{*}(<0.05)=$ Significant, ${ }^{* *}(<0.01)=$ Highly significant, ${ }^{* * *}(<0.001)=$ Very

Highly Significant $(n=6)$
For flavonoid determination, the regression equation of the calibration curve was $\left(y=0.000 x+0.021, R^{2}=0.992\right)$ and expressed as quercetin equivalent (QE) exposed in Table 5 and Fig. 3.

In the reducing power assay, SA was assayed for the reducing power activity where ascorbic acid was used as a standard. It has shown in vitro ferric reducing potential given in Table 6 and Fig. 4.

The cytotoxic activity of the extract was determined in accordance with the BSLT and expressed as the $\mathrm{LC}_{50}$ value (Table 7 and Fig. 5 and 6).

\section{DISCUSSION}

In the traditional systems of medicine, certain plants are claimed to provide relief from pain and inflammation. In the current study, plant $S$. asper roots were taken for the study. $S$. asper is a well-known ethnomedicinal plant. It is also used in Ayurveda [15,22]. Analgesic activities were evaluated by two animal models, which could respond to two different grades of noxious stimuli [33]

Acetic acid causes an increase in peritoneal fluids of Prostaglandin $E_{2}$ $\mathrm{PGE}_{2}$ and Prostaglandin $\mathrm{F}_{2}{ }^{\alpha} \mathrm{PGF}_{2}{ }^{\alpha}$ serotonin, and histamine, which are a model commonly used for screening peripheral analgesics [34,35]. With respect to the acetic acid-induced abdominal writhing which is the visceral pain model [36]. The results are presented in Table 1 showed that the ethanolic extract of the roots of $S$. asper induced a significant decrease in the number of writhes when compared to the control. The SA extracts of $250 \mathrm{mg} / \mathrm{kg}, 500 \mathrm{mg} / \mathrm{kg}$ thus possessed significant $(\mathrm{p}<0.05)$ analgesic effect where reference drug diclofenac at $100 \mathrm{mg} / \mathrm{kg}$ exhibited the highest analgesic power. Both the doses inhibited pain at $6 \%$ and $29 \%$, respectively, indicating that the extract had an analgesic effect than the reference drug employed in this study. In general, acetic acid causes pain by liberating endogenous substances such as serotonin, histamine, PGs, bradykinins, and substance P [37]. The method has also been associated with prostanoids in general, that is, increased levels of $\mathrm{PGE}_{2}$ and $\mathrm{PGF}_{2}{ }^{\alpha}$ in peritoneal fluids, as well as lipoxygenase products $[34,38]$. The reduction in acetic acid-induced writhes of $S$. asper suggests that the analgesic effect may be peripherally mediated through the inhibition of synthesis and release of PGs and other endogenous substances.

The formalin test is believed to be a more valid analgesic model which is better correlated with clinical pain $[39,40]$. The formalin test is biphasic, and measures pain in both neurogenic (first phase) and inflammatory origin (second phase). The first phase (0-5 min) being a result of direct stimulation of nociceptors measures centrally mediated effects and insensitive to anti-inflammatory agents while the second phase (15-30 min) which is qualitatively different from the first phase is dependent on peripheral inflammation and changes in central procession due to chemical mediators released from damaged cells that stimulate nociception and thus induced pain [26]. The results of this study, presented in Table 2, indicate that the ethanolic extract of $S$. asper caused a dose-dependent decrease in licking time and licking frequency in mice injected with formalin. This inhibitory effect is more pronounced in the later phase. The ability of SA ethanolic extract to inhibit late phases of the formalin test more prominently indicates its involvement in the peripherally mediated activity, probably by prostaglandin synthesis inhibition. The results of the analgesic study suggested that the ethanolic extract of SA process good analgesic activity by inhibition of peripheral mediators.

Table 2: The effect of control, STD (Diclofenac-Na), SA $250 \mathrm{mg}$, and SA $500 \mathrm{mg}$ in the formalin-induced paw licking test (1 ${ }^{\text {st }}$ and $2^{\text {nd }} 5 \mathrm{~min}$ )

\begin{tabular}{|c|c|c|c|c|}
\hline \multirow[t]{2}{*}{ Group } & \multicolumn{2}{|l|}{$1^{\text {st }} 5 \mathrm{~min}$} & \multicolumn{2}{|l|}{$2^{\text {nd }} 5 \mathrm{~min}$} \\
\hline & Licking Time (mean \pm SEM) & \%Inhibition of Inflammation & Licking Time (mean \pm SEM) & $\%$ Inhibition of pain \\
\hline Control & $36.67 \pm 1.76$ & 00 & $31 \pm 2.79$ & 00 \\
\hline Std (Diclofenac-Na) & $8.67 \pm 2.03^{* * *}$ & 75.92 & $6.00 \pm 1.51^{* * *}$ & 80.65 \\
\hline ESA $250 \mathrm{mg}$ & $26.67 \pm 3.24 *$ & 25.92 & $13.67 \pm 3.85^{* *}$ & 39.78 \\
\hline ESA $500 \mathrm{mg}$ & $26.0 \pm 2.22^{* *}$ & 27.78 & $18.67 \pm 0.67^{* *}$ & 55.93 \\
\hline
\end{tabular}

N.B: ${ }^{*}(<0.05)=$ Significant, ${ }^{* *}(<0.01)=$ Highly Significant, ${ }^{* * *}(<0.001)=$ Very Highly Significant $(\mathrm{n}=6)$ 
Table 3: IC $_{50}$ values of the STD (ascorbic acid) and SA extract

\begin{tabular}{ll}
\hline Plant sample/STD & IC $_{\mathbf{5 0}}(\mu \mathrm{g} / \mathbf{m l})$ \\
\hline Ascorbic acid (STD) & 16.88 \\
(SA ethanolic extract) & 1143.16 \\
\hline
\end{tabular}

Values expressed as a means of duplicating experiments and represented as mean \pm SD

Table 4: Total phenol contents of the ethanolic extract of SA

\begin{tabular}{ll}
\hline Plants/Samples & Total flavonoid content $(\mathbf{m g} / \mathbf{g}, \mathbf{Q E})$ \\
\hline (SA extract) & $134.67 \pm 2.00$
\end{tabular}

Value is expressed as a means of duplicating experiments and represented as mean \pm SD

Table 5: Total flavonoid contents of the ethanol extract of SA

\begin{tabular}{ll}
\hline $\begin{array}{l}\text { Plants/ } \\
\text { Samples }\end{array}$ & $\begin{array}{l}\text { Total phenol content } \\
\text { (mg/g, gallic acid equivalents) }\end{array}$ \\
\hline (SA extract) & $118.33 \pm 14.14$ \\
\hline
\end{tabular}

Value is expressed as a means of duplicating experiments and represented as mean \pm SD

Table 6: Reducing power capacity of the ethanolic extract of SA

\begin{tabular}{ll}
\hline $\begin{array}{l}\text { Plants/ } \\
\text { Samples }\end{array}$ & $\begin{array}{l}\text { Reducing power capacity of } \\
\text { SA (mg/g, ascorbic acid) }\end{array}$ \\
\hline (SA ethanolic extract) & $805.5 \pm 38.90$ \\
\hline
\end{tabular}

Value is expressed as a means of duplicating experiments and represented as mean \pm SD

Antioxidants are substances that stabilize the molecule, preventing damage to other cells caused by free radicals by supplying electrons [41]. Natural antioxidants are either in the form of raw extracts or their chemical constituents are very effective to prevent the destructive processes caused by oxidative stress [12]. The secondary metabolites such as phenolics and flavonoids from plants have been reported to be potent free-radical scavengers [42]. Antioxidant molecules can quench DPPH free radicals either by electron donation or by providing hydrogen atoms resulting in a decrease in absorbance at $517 \mathrm{~nm}$. This test is a commonly employed assay in antioxidant studies of specific compounds or extracts across a short time scale [43]. The $\mathrm{IC}_{50}$ values of DPPH radical scavenging activity are shown in Table 3 and Fig. 1. $\mathrm{IC}_{50}$ values of the sample and ascorbic acids were $1143.16 \mu \mathrm{g} / \mathrm{ml}$ and $16.88 \mu \mathrm{g} / \mathrm{ml}$, respectively. Although our results indicate that the DPPH radical scavenging activity of SA extract is lower than ascorbic acid; it can serve as a free radical scavenger, acting possibly as an antioxidant.

Plant phenolics constitute one of the major classes of compounds that act as natural antioxidants [44]. The antioxidant activity of phenolic compounds and flavonoids is attributed to the hydroxyl group attached to the aromatic ring, which is capable of donating electrons and stabilizing free radicals [45]. The total phenolic content was found to be $118.33 \pm 14.14 \mathrm{mg} / \mathrm{g}$ gallic acid equivalents (Table 4 and Fig. 2). Flavonoids are known as an excellent free-radical scavenging agents and management of diabetes and its complications [45-48]. Therefore, it was reasonable to believe the total flavonoid contents of SA extract. The total flavonoid compounds were found to be $134.67 \pm 2.0 \mathrm{mg} / \mathrm{g}$ quercetin equivalents. In the reducing power assay, the presence of antioxidants in the sample would result in the reduction of $\mathrm{Fe}^{3+}$ to $\mathrm{Fe}^{2+}$ by donating an electron. The amount of $\mathrm{Fe}^{2+}$ complex can then be monitored by measuring the formation of Perl's blue at $700 \mathrm{~nm}$. Increased absorbance indicates an increase in reductive ability [49]. Reducing the power of a compound serves as a significant indicator of its antioxidant activity [50]. S. asper was assayed for reducing power activity where ascorbic acid was used as a standard. The results of reducing power capacity shown

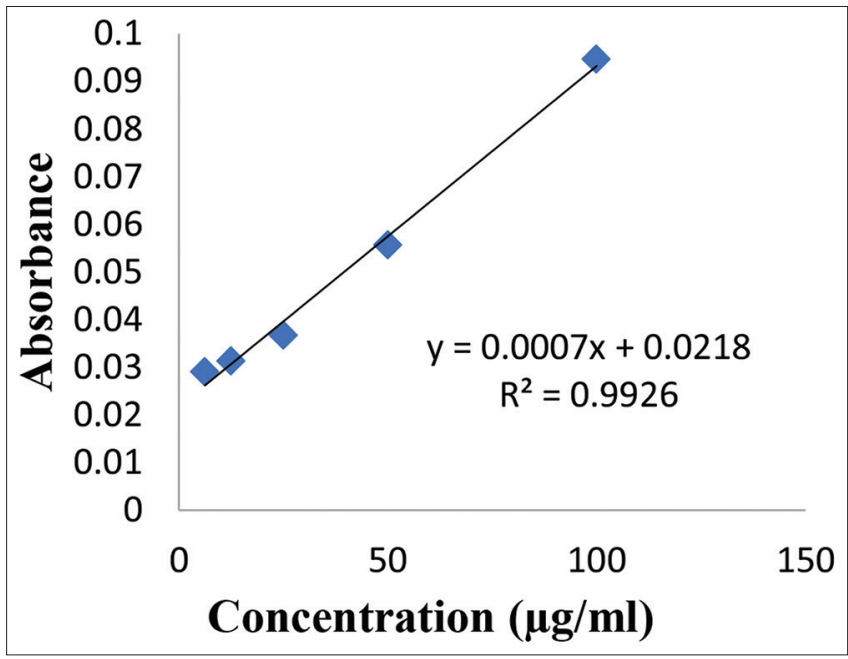

Fig. 3: Calibration curve of quercetin

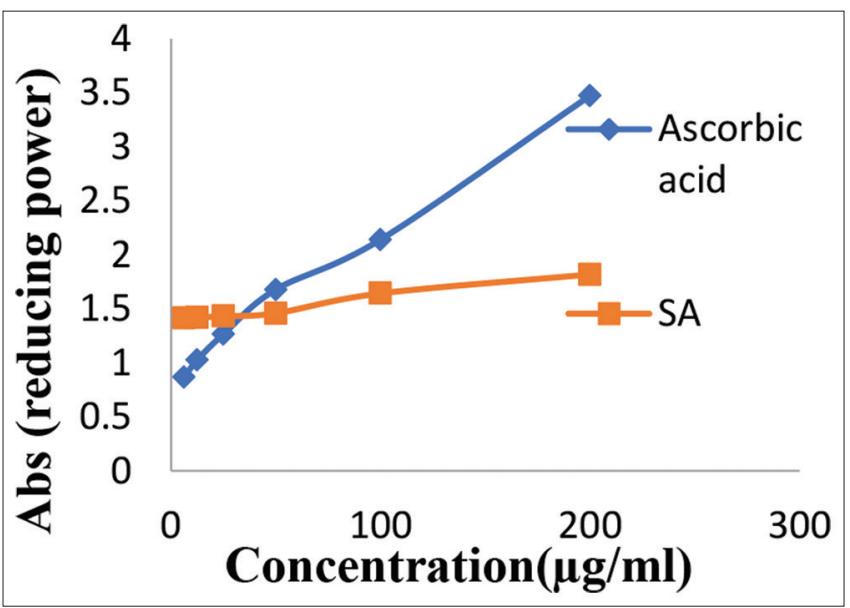

Fig. 4: Reducing power of ascorbic acid and ethanolic extract of Streblus asper

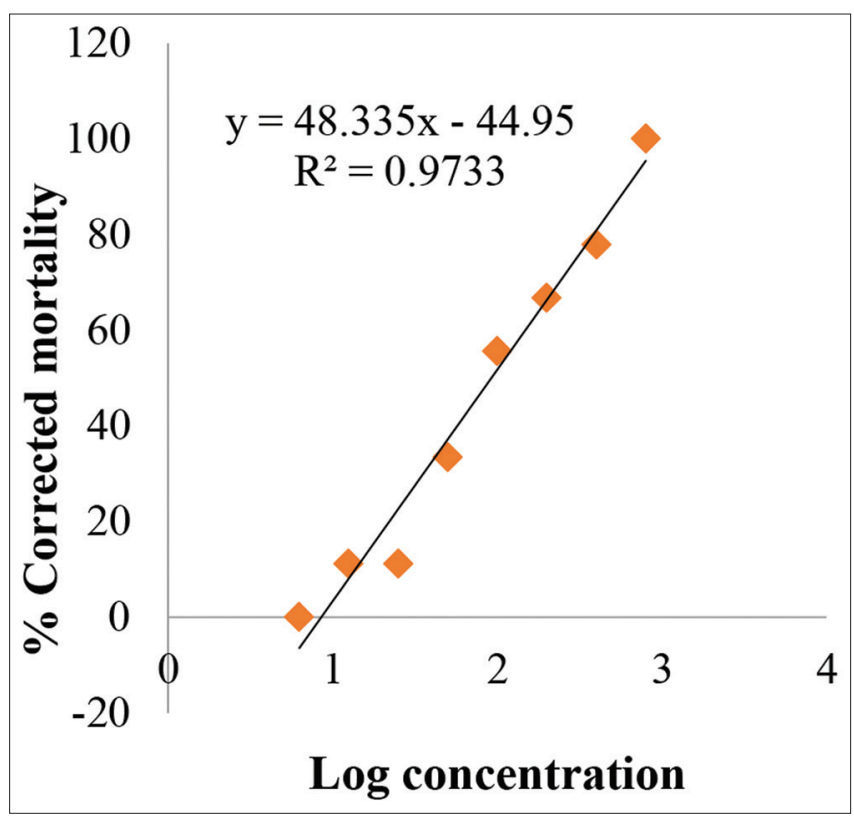

Fig. 5: Graphical presentation of the cytotoxic potential of SA extract 
Table 7: Brine shrimps lethality bioassay of the ethanolic extract of SA roots and vincristine sulfate

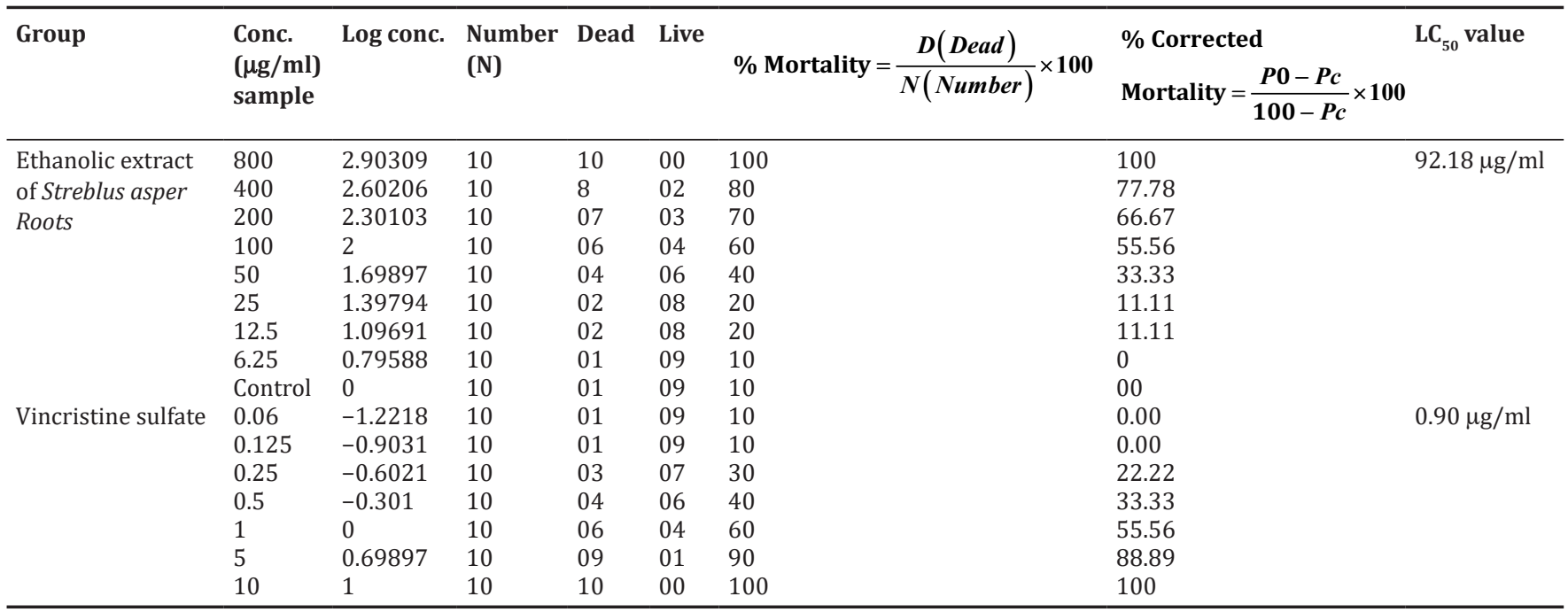



Fig. 6: Graphical presentation of cytotoxicity of vincristine sulfate

in Table 6 and Fig. 4, which is $805.5 \pm 38.90 \mathrm{mg} / \mathrm{g}$ of ascorbic acid equivalents. That indicates the good reducing power capacity compared to standard. The antioxidant assays recommend that SA roots ethanolic extract exhibit good antioxidant property due to the presence of a higher amount of phenolic and flavonoid content.

A general bioassay that appears capable of detecting a broad spectrum of bioactivity present in crude extracts is the BSLT. It appears that BSLT is predictive of cytotoxicity and pesticidal activity and is commonly used in the bioassay for the bioactive compounds $[51,52]$. The cytotoxic activity of the extract was determined by the BSLT and expressed as the $\mathrm{LC}_{50}$ value (Table 7 and Fig. 5 and 6). $\mathrm{LC}_{50}$ values for SA ethanolic extract and vincristine sulfate were $92.18 \mu \mathrm{g} / \mathrm{ml}$ and $0.90 \mu \mathrm{g} / \mathrm{ml}$, respectively. The $\mathrm{LC}_{50}$ value of the $\mathrm{SA}$ extracts is shown that the extract is highly cytotoxic compare to the standard. It may be due to the presence of different phytochemical constituents.

\section{CONCLUSION}

The results of the experiments in this study indicate that the ethanolic extract of $S$. asper (roots) possesses good analgesic properties in both models. The extract also showed beneficial antioxidant potential against free radicals. The higher contents of flavonoids and phenolics support the assumption. It is also supported by high reducing power capacity. From the study of cytotoxic activity, it can be asserted that the investigated plant materials $S$. asper is a viable source of natural cytotoxic agents which might be due to the presence of different phytoconstituents. Therefore, it can be demonstrated that the ethanolic extract of S. asper (roots) possesses analgesic, antioxidant as well as significant cytotoxic properties. This could provide a rationale for the use of this plant in various disorders in folk medicine. Further sophisticated study is required to isolate the active principle by bioassay-guided fractionation and other methods for the management of diseases.

\section{ACKNOWLEDGMENTS}

The authors are grateful to the Department of Pharmacy, Gono Bishwbidyalay, Savar, Dhaka-1344, and Jahngirnagar University, Savar, Dhaka for the laboratory facility to conduct the research work.

\section{AUTHOR'S CONTRIBUTIONS}

The authors have equally been involved in this research work. All the authors have read and agreed to the final approval of the manuscript.

\section{CONFLICT OF INTEREST}

All the authors professed that they do not have any conflicts of interest in publishing this research article.

\section{AUTHOR'S FUNDING}

This work is completely funded by authors.

\section{REFERENCES}

1. Goldsby RA, Kindt TJ, Osborne BA, Kuby J. Immunology. $5^{\text {th }}$ ed. New York: W. H. Freeman and Company; 2003.

2. Kumpulainen JT, Salonen JT. Natural Antioxidants and Anticarcinogens in Nutrition, Health and Disease. Cambridge: Woodhead Publishing; 1999.

3. Alkofahi A, Rupprecht JK, Smith DL, Chnag CJ, Mclaughlin JL. Goniothalamicin and annonacin: Bioactive acetogenins from Goniothalamus giganteus (Annonaceae). Experinetia 1988;44:83-5.

4. Kameswara RB, Giri R, Kesavulu MM, Apparao C. Effect of oral administration of bark extracts of Pterocarpus santalinus L. on blood glucose level in experimental animals. J Ethnopharmacol 2001;74:69-74.

5. Kedziora-Kornatowska K, Szram S, Kornatowski T, SzadujkisSzadurski L, Kedziora J, Bartosz G. The effect of verapamil on the antioxidant defence system in diabetic kidney. J Clin Chim Acta 2002;322:105-12.

6. Cai Y, Luo Q, Sun M, Corke H. Antioxidant activity and phenolic compounds of 112 traditional Chinese medicinal plants associated with 
anticancer. Life Sci 2004;74:2157-84.

7. Gurung R. Preliminary phytochemical screening, total phenol and flavonoid content of Mimosa rubicaulis and Reinwardita indica. Int J Pharm Pharm Sci 2020;12:54-8.

8. Vadivel E, Tendulkar RD, Harmalkar VV. Comparative anti-oxidant and anthelmintic activity of Dalbergia sissoo roxb ex dc and Dalbergia latifolia roxb ex dc. Int J Curr Pharm Res 2015;7:70-2.

9. McLaughlin JL, McLaughlin J. Crown gall tumours in potato discs and brine shrimp lethality: Two simple bioassays for higher plant screening and fractionation. J Methods Plant Biochem 1991;6:1-31.

10. Maqsood S, Benjakul S. Comparative studies of four different phenolic compounds on in vitro antioxidative activity and the preventive effect on lipid oxidation of fish oil emulsion and fish mince. Food Chem 2011;119:123-32.

11. Hamed MM, Mohamed MA, Ahmed WS. Antioxidant potential, antitumor activity and phenolic profile of Phoenix dactylifera Linn. Int J Pharm Pharm Sci 2017;9:130-6.

12. Zengin G, Aktumsek A, Guler GO, Cakmak YS, Yildiztugay E. Antioxidant properties of methanolic extract and fatty acid composition of Centaurea urvillei DC. subsp. Hayekiana Wagenitz. Rec Nat Prod 2011;5:123-32.

13. Karunakar S. Bioassay: An uncomplicated methodologies for ensure safety of traditional formulations. Res J Pharmacogn Phytochem 2009;1:1-4.

14. Glasby JS. Dictionary of Plants Containing Secondary Metabolites. Besingstoke: Taylor and Francis; 1991.

15. Chopra RN, Nayar SL, Chopra IC, Asolkar LV, Kakhar KK. Glossary of Indian Medicinal Plants. New Delhi: Council of Scientific and Industrial Research; 1956-1992.

16. Missouri Botanical Garden Press. Flora of China. Vol. 5. Beijing: Missouri Botanical Garden Press; 2003. p. 1-3.

17. Hooker JD. Botanical observations made in a journey to the Naga Hills (between Assam and Muneypore). J Linn Soc Lond Bot 1886;22:128-36.

18. Taweechaisupapong P, Klanrit P, Singhara S, Pitiphat W, Wongklam S. Inhibitory effect of Streblus asper leaf-extract on adhesion of Candida albicans to denture acrylic. J Ethnopharmacol 2006;106:414-7.

19. Rastogi S, Kulshreshtha DK, RawatAK. Streblus asper lour. (Shakhotaka): A review of its chemical, pharmacological and ethnomedicinal properties. Evid Bas Complement Altern Med 2006;3:217-22.

20. Gaitonde BB, Vaz AX, Patel JR. Chemical and pharmacological study of root bark of Streblus asper Linn. Indian J Med Sci 1964;18:191-9.

21. Wongkham S, Laupattarakasaem P, Pienthaweechai K, Areejitranusorn P, Wongkham C, Techanitiswad T. Antimicrobial activity of Streblus asper leaf extract. Phytother Res 2001;15:119-21.

22. Niscom Tele Infra. Useful Plants of India. New Delhi: Niscom Tele Infra; 1992. p. 603-4.

23. Jain SK. Dictionary of Indian Folk Medicine and Ethnobotany: A Reference Manual of Man-plant Relationships, Ethnic Groups and Ethnobotanists in India. New Delhi: Deep Publications; 1991.

24. Bhakuni DS, Dhar ML, Dhar MM, Dhawan BN, Mehrotra BN. Screening of Indian plants for biological activity. II. Indian J Exp Biol 1969;7:250-62.

25. Koster R, Anderson M, De-Beer EJ. Acetic acid analgesic screening. Fed Proc 1959;18:412-7.

26. Hunskaar S, Hole K. The formalin test in mice: Dissociation between inflammatory and non-inflammatory pain. Pain 1987;30:103-14.

27. Silva IK, Soysa P. Evaluation of phytochemical composition and antioxidant capacity of a decoction containing Adenanthera pavonina L. and Thespesia populnea L. Pharmacogn Mag 2011;7:193-9.

28. Ordonez AA, Gomez JD, Vattuone MA, Isla MI. Antioxidant activities of Sechium edule (Jacq.) Swart extracts. Food Chem 2006;97:452-8.

29. Alnajar ZA, Abdulla MA, Ali HM, Alshawsh MA, Hadi AH. Acute toxicity evaluation, antibacterial, antioxidant and immunomodulatory effects of Melastoma malabathricum. Molecules 2012;17:3547-59.

30. Mayakrishnan V, Abdullah N, Abidin MH, Hamdi M. Investigation of the antioxidative potential of various solvent fractions from fruiting bodies of Schizophyllum commune (Fr.) mushrooms and characterization of phytoconstituents. J Agric Sci 2013;5:58-68.

31. Islam S, Nasrin S, Khan MA, Hossain AS, Islam F, Khandokhar P, et al.
Evaluation of antioxidant and anticancer properties of the seed extracts of Syzygium fruticosum Roxb. growing in Rajshahi, Bangladesh. BMC Complement Altern Med 2013;13:142.

32. Meyer BN, Ferrigni NR, Putnam JE, Jacobsen LB, Nichols DE, McLaughlin JL. Brine shrimp: A convenient general bioassay for active plant constituents. Planta Med 1982;45:31-4

33. Victor BO, Caleb OW, Ayodele OS, Samuel BO. Studies on the antiinflammatory and analgesic properties of Tithonia diversifolia leaf extract. J Ethnopharmacol 2004;90:317-21.

34. Deraedt R, Jouquey S, Delevallée F, Flahaut M. Release of prostaglandins $\mathrm{E}$ and $\mathrm{F}$ in an algogenic reaction and its inhibition. Eur $\mathrm{J}$ Pharmcol 1980;51:17-24.

35. Collier HO, Dinneen LC, Johnson CA, Schneider C. The abdominal constriction response and its suppression by analgesic drugs in the mouse. Br J Pharmacol Chemother 1968;32:295-310.

36. Vyklicky L. Techniques for the study of pain in animals. In: Bonica JJ, Liebeskind JC, Albe-Fessard DG, editors. Advances in Pain Research and Therapy. New York: Raven Press; 1979. p. 773-8.

37. Bentley GA, Newton SH, Starr J. Studies on the antinociceptive action of alpha-agonist drugs and their interactions with opioid mechanisms. Br J Pharmacol 1983;79:125-34

38. Roberts LJ, Morrow JD. Analgesic, antipyretic and anti-inflammatory agents and drugs employed in the treatment of gout. In: Goodman and Gilman's the Pharmacological Basis of Therapeutics. $10^{\text {th }}$ ed. New York: McGraw-Hill; 2001. p. 687-732.

39. Tjølsen A, Berge OG, Hunskaar S, Rosland JH, Hole K. The formalin test: An evaluation of the method. Pain 1992;51:5-17.

40. Ghannadi A, Hajhashemi V, Jafarabadi H. An investigation of the analgesic and anti-inflammatory effects of Nigella sativa seed polyphenols. J Med Food 2005;8:488-93.

41. Giovannucci E, Rimm EB, Liu Y, Stampfer MJ, Willett WC. A prospective study of tomato products, lycopene, and prostate cancer risk. J Nat Cancer Inst 2002;94:391-8.

42. Chanda S, Dave R. In vitro models for antioxidant activity evaluation and some medicinal plants possessing antioxidant properties: An overview. Afr J Microbiol Res 2009;3:981-96.

43. Graziani G, D'Argenio G, Tuccillo C, Loguercio C, Ritieni A, Morisco F, et al. Apple polyphenol extracts prevent damage to human gastric epithelial cells in vitro and to rat gastric mucosa in vivo. Gut 2005;54:193-200.

44. Veeru P, Kishor MP, Meenakshi M. Screening of medicinal plant extracts for antioxidant activity. J Med Plants Res 2009;3:608-12.

45. Dorman DH, Koşar M, Kahlos K, Holm Y. Antioxidant properties and composition of aqueous extracts from Mentha species, hybrids, varieties, and cultivars. J Agric Food Chem 2003;51:4563-9.

46. Yao LH, Jiang YM, Shi J, Tomás-Barberán FA, Datta N, Singanusong R, et al. Flavonoids in food and their health benefits. Plant Foods Hum Nutr 2004;59:113-22.

47. Tepe B, Daferera D, Sokmen A, Sokmen M, Polissiou M. Antimicrobial and antioxidant activities of the essential oil and various extracts of Salvia tomentosa Miller (Lamiaceae). Food Chem 2005;90:333-40.

48. Süzgeç S, Meriçli AH, Peter JH, Çubukçu B. Flavonoids of Helichrysum compactum and their antioxidant and antibacterial activity. Fitoterapia 2005;76:269-72

49. Aiyegoro OA, Okoh AI. Preliminary phytochemical screening and In vitro antioxidant activities of the aqueous extract of Helichrysum longifolium DC. BMC Complement Altern Med 2010;10:21.

50. Bhaumik UK, Kumar DA, Selvan VT, Saha P, Gupta M, Mazumder UK. Antioxidant and free radical scavenging property of methanol extract of Blumea lanceolaria leaf in different in vitro models. Pharmacologyonline 2007;2:74-89.

51. Ghisalberti EL. Detection and isolation of bioactive natural products. In: Colegate SM, Molyneux RJ, editors. Bioactive Natural Products: Detection, Isolation, and Structural Determination. Boca Raton: CRC Press; 1993. p. 15-8.

52. Zhao GX, Hui YH, Rupprecht JK, McLaughlin JL, Wood KV. Additional bioactive compounds and trilobacin, a novel highly cytotoxic acetogenin, from the bark of Asimina triloba. J Nat Prod 1992;55:347-56. 